\title{
Postpartum depression and child development in first year of life
}

\author{
Depressão pós-parto e desenvolvimento \\ do bebê no primeiro ano de vida
}

\author{
Maria de Lima Salum e MORAIS \\ Tania Kiehl LUCCI ${ }^{2}$ \\ Emma OTTA ${ }^{2}$
}

\begin{abstract}
The aim of the study was to investigate the characteristics of infant development at four, eight and twelve months of age, as result of postpartum depression. The prevalence of Postpartum Depression - measured by the Edinburgh Postnatal Depression Scale - at four months after delivery was 30.3\%; at eight months, 26.4\%; and at 12 months, 25.0\%. Chi-square tests were used to compare children of mothers with and without Postpartum Depression in relation to developmental milestones. It was found developmental delay in infants of mothers with Postpartum Depression in: two interactional indicators at four months, two motor indicators at eight months and one gross motor indicator at twelve months. However, children of mothers with Postpartum Depression showed better results in one fine motor and in two language items at 12 months. The results point to the necessity of considering external and internal factors of mother and infant in the study of the effects of maternal depression on child development.
\end{abstract}

Uniterms: Childhood development; Depression, postpartum; Mother-child relations.

\section{Resumo}

Oobjetivo do estudo foi investigar características do desenvolvimento infantil aos 4, 8 e 12 meses de idade em função de depressão pós-parto. A porcentagem de mães com depressão pós-parto - medida pela Escala de Depressão Pós-parto de Edimburgo -, aos 4 meses após o parto foi de 30,3\%; aos 8 meses, 26,4\%; e, aos 12, 25,0\%. Utilizaram-se testes de Qui-quadrado para comparar filhos de mães com e sem depressão pós-parto em relação a marcos do desenvolvimento. Constatou-se pior desempenho de bebês de mães deprimidas em: 2 indicadores interacionais aos 4 meses, 2 indicadores motores aos 8 meses, e 1 indicador motor amplo aos 12 meses. Filhos de mães com depressão pós-parto, contudo, mostraram melhores resultados em 1 indicador de motricidade fina e em 2 de linguagem aos 12 meses. Conclui-se pela necessidade de considerar fatores externos e internos da mãe e do bebê no estudo dos efeitos da depressão materna sobre o desenvolvimento infantil.

Unitermos: Desenvolvimento infantil; Depressão pós-parto; Relação mãe-criança.

$\boldsymbol{\nabla \nabla \nabla \nabla}$

1 Instituto de Saúde, Núcleo de Práticas da Saúde. R. Santo Antônio, 590, $3^{\circ}$ andar, Bela Vista, 01314-000, São Paulo, SP, Brasil. Correspondence to/Correspondência para: M.L.S. MORAIS. E-mail: <salum@isaude.sp.gov.br>

2 Universidade de São Paulo, Instituto de Psicologia. São Paulo, SP, Brasil.

Apoio: Fundação de Amparo a Pesquisa do Estado de São Paulo (Processo no 06/59192-2). 
Postpartum Depression (PPD) is a depressive disorder that happens to mothers in puerperum stage, between four and twelve weeks after the baby is born (IDC 10) and is characterized by manifestations with varying levels of occurence and intensity of depressed humor, difficulties to concentrate, guilt feelings, lack of stamina, lack of energy and pleasure performing everyday activities, lack of interest for life in general, feelings of incapacity, lack of support and hopelessness. Such maternal characteristics affect the interaction between a mother and her children, and may have consequences in the development of the child (Motta, Lucion \& Manfro, 2005; Ribeiro, 2002; Schwengber \& Piccinini, 2003; Tronick \&Weinberg, 1997).

Studies on the impact of postpartum depression on mother-infant interaction suggest that one of the most important effects concerns the impairment of the face-to-face exchanges (Beck, 1998; Frizzo \& Piccinini, 2007). According to Tronick and Weinberg (1997), the ability of mutual regulation of the mother-infant dyad in intersubjective exchanges determines the course of social, emotional and cognitive development. Frizzo and Piccinini (2005) and Schwengber and Piccinini (2003) summarize research findings that compared depressed mothers with non-depressed mothers: the first spent less time watching, playing and talking with their babies; had more negative than positive expressions; showed less contingent responsiveness, less spontaneity and lower activity levels. The babies of depressed mothers showed less positive affect, lower activity levels, less vocalization, greater distancing from the look, fewer expressions of interest and more intense protests. Motta et al. (2005) reported other effects of maternal depression on the psychological development of children: greater vulnerability to anxiety, less positive affection, less positive interaction with their mothers and with strangers, increased production of glucocorticoids, which may be associated with less adaptive ways of coping with stress due to difficulties for caregivers to deal with stressors for baby.

Although these studies show clearly the risk that depression represents for the mother and for the development of her baby, the data is not clear and there are studies whose findings suggest that several factors may offset the effects of depression on parental behavior

8 (Boyd, Zayas \& Mckee, 2006; Fonseca, Silva \& Otta, 2010;
Grote et al., 2010; Hartley et al., 2010). Boyd et al. (2006), studying a group of African-American and Hispanic mothers, did not find significant differences were found between indicators of maternal interaction due to the depression and it found that only the positive events of the mother's life were directly associated with the interaction rate of babies. Grote et al. (2010), in a study with mothers in Europe, concluded that high rates of postnatal depression, as measured by the Scale of Edinburgh, had no significant effect on the growth of children in developed countries. Fonseca et al. (2010) found no significant effect of postpartum depression on the interaction of mother-child dyads. Hartley et al. (2010) found that maternal postpartum depression was not associated with social withdrawal in babies between ten and twelve months of age.

Among the factors that may account for the different findings about the influence of postpartum depression on the development and behavior of children, are, on the part of mother: the support she receives from her partner, family and friends, her ability to deal with symptoms of depression in the relationship with the baby, the period, the duration and the severity level of depression. On the part of the baby, factors such as temperament, resilience and time spent with the mother, among others, may be responsible for behavioral variations (Canadian Paediatric Society, 2004).

The development is a product of the interaction among biological and behavioral characteristics of the child and the physical and sociocultural environment where they are inserted (Knobloch \& Passamanick, 1990; Wallon, 1941/1995). From birth throughout life, the child suffers from several environmental influences of all kinds. The isolated effect of maternal depression is unlikely to be observed, because, in addition to maternal characteristics, environmental factors such as prenatal environment, including chemical balance and the presence of toxic substances in the mother's body, contribute to the development of the baby; the physical environment, involving nutritional aspects and conditions that expose children to diseases and accidents; the sociocultural environment, including norms, beliefs, values and behavior patterns existing in the environment in which the child lives; the learning environment, which involves the type of sensory, motor and cognitive stimulation that the child receives. 
Sapienza and Pedromônaco (2005) highlight as risk factors for development: from the biological point of view, prematurity, low birth weight, brain damage; from the social perspective, being part of minority groups, parental unemployment, poverty, limited access to health and education; and from the emotional point of view, exposure to stressful events. Among the protection factors for child development, Haggerty, Sherrod, Gamezy and Rutter (2000) mentioned: receiving care and having adequate models, having stable and secure bonds, as well as protection and social support.

Despite the existing differences in the environments in which children grow and their special characteristics, it is possible to assess their development, "because the construction of the action system of the baby and the child's is an orderly process" (Knobloch \& Passamanick, 1990, p.4): the order in which behavioral milestones happen and the chronological age in which each of these is expected follows a certain pattern. Given the complexity of human behavior, Knobloch and Passamanick (1990), who proposed an evaluation system of child development from four weeks to 36 months of life, according to Gesell, devided the behavior into five different areas: adaptive behavior, gross motor behavior, fine motor behavior, language and personal-social behavior. Adaptive behavior corresponds to the organization of the stimuli, the perception of relationships between parts and the whole, the finer sensorimotor adjustments, visuomotor coordination and problem solving skills that involve properly using the motor apparatus. The gross motor behavior involves postures, keeping the balance of the head, sitting, standing up, crawling and walking, while the fine motor behavior consists of using the hands and fingers to manipulate objects. Language involves the visible and audible forms of communication, that is, verbal and non-verbal communication, and the social-personal behavior affects relationships and the adaptations to the culture in which the child lives. The authors emphasize that all areas overlap.

The Denver II test, applicable from fifteen days to six years of age, divided development into four domains: personal-social, motor-adaptive, language and gross motor domains (Frankenburg, Dodds, Archer, Shapiro \& Bresnick, 1990). The personal-social component regards the interaction with people; the fine adaptive component involves visuomotor coordination and manipulation of small objects; the language component involves listening and understanding words and gestures and expressing themselves verbally or with gestures; the gross motor component comprises sitting, walking, jumping and performing other large muscle movements.

The scale M-Chat, created by Robins, Fein, Barton and Green (2001) to detect signs of autism disorders and the clinical Indicators of Risk for Child Development (Indicadores Clínicos de Risco para o Desenvolvimento Infanti I - IRDI) by Kupfer et al. (2010) have the advantage of proposing additional items, especially focused on child's interaction, increasing the chances of detecting problems in this area. Robins (2008) highlights its importance as a screening tool for developmental problems, being desirable that it be applied in childcare. As most studies indicate effects of maternal depression in the interactional field, some items of the scale are also used in this work. The subdivision of development in domains used in this study helps us better understand in which areas and in what way the child's behavior can be affected by risk factors, such as maternal depression.

Given the undeniable importance of the phenomenon of PPD and its possible repercussions for the mother and the baby, and considering the inconsistency of findings from other studies, we have attempted, in the present work, to compare characteristics of neuropsychomotor development at four, eight and twelve months of age in children of mothers with signs of PPD, as assessed by the Scale for Postpartum Depression Edinburgh (EDPE), with children of non-depressed mothers of the same cohort, living in West periphery of the city of São Paulo. In order to evaluate the development of babies, some milestones were selected from the requisites presented by Frankenburg et al. (1990), Knobloch and Passamanick (1990), Kupfer et al. (2010) and Robins et al. (2001). The purpose of adapting the instruments was to contemplate the detection of the presence or absence of some development indicators, in order to compare the behavior of babies born to mothers with and without PPD, with no intention of assessing how the children examined were located within certain standards of normality. 


\section{Method}

\section{Participants}

Pregnant women in prenatal care who intended to give birth at the University Hospital of the University of São Paulo were enrolled in Basic Health Units of the West area of the city of São Paulo, in the period between 2006 and 2008. We intended to monitor these mothers and their children at four, eight, twelve, 24 and 36 months of life. For various reasons however, there were several losses with time. The interviews were conducted at the Institute of Psychology of the University of São Paulo (Universidade de São Paulo), where, according the child's age, there were other procedures with the dyads.

The following cuts were made, resulting in subsamples from the same cohort: with babies at four months \pm 13 days of age, 76 dyads were interviewed/ observed, and 23 of them (30.3\%) had evidence of PPD; with babies at eight months \pm 13 days of age 87 dyads were studied, 23 (26.4\%) of them with PPD; with babies at twelve months \pm 13 days of age, 78 dyads were studied, being 19 mothers (25.0\%) assessed as suffering from PPD. The margin of days for more or less was given with the intention of getting a similar number of mothers in the three subsamples and considering that, in designing the instrument, it had already been considered a margin of 20 days to a month in advance to acquiring the evaluated behavior. Premature infants, a couple of twins and a girl who had evidence of delayed global development were eliminated from the sample.

In this same project, R. Felipe (oral communication, $2011)^{3}$ ranked mothers according to socioeconomic resources, using the economic classification of the Brazilian Association of Research Companies (Associação Brasileira de Empresas de Pesquisa, 2009), noting that 23.0\% of mothers were Class B, $66.7 \%$ of Class C and $10.3 \%$ to classes $D$ and $E$; therefore, most mothers could be considered as belonging to the lower middle class. Other data of subsamples are shown in Table 1.

\section{Instruments}

The Edinburgh Postnatal Depression Scale (EPDS) focuses on identifying symptoms of PPD. It has

\section{Table 1}

Composition of subsamples at 4, 8 and 12 months of baby's age. São Paulo (SP), 2006-2007

\begin{tabular}{lccc}
\hline \multirow{2}{*}{ Variable } & \multicolumn{3}{c}{ Baby's age } \\
\cline { 2 - 4 } & 4 months $(n=76) \%$ & 8 months $(n=87) \%$ & 12 months $(n=78) \%$ \\
\hline Percentage of mothers with PPD according to EPDS & 30.3 & 26.4 & 25 \\
Gender of the baby & & & 64.1 \\
Female & 65.4 & 31.8 & 35.9 \\
Male & 34.6 & 24 years old & 24 years old \\
Median age of mother & 25 years old & & 26.4 \\
Mother's years in school & & 25 & 65.3 \\
Up to 8 years & 22.1 & 71.4 & 8.3 \\
Between 9 and 12 & 71.6 & 3.6 & 76.2 \\
13 or more & 2.6 & 74.1 & 21.8 \\
Marital Status & & 35.9 & 78.2 \\
Married or living with a companion & 69.2 & & 21.8 \\
Single/separated/divorced & 30.8 & 83.1 & \\
Number of children & & 16.9 & \\
One child & 76.5 & & \\
Two or more & 23.5 & & \\
\hline
\end{tabular}

Note: PPD: Postpartum Depression; EPDS: Edinburgh Postnatal Depression Scale.

3 De Felipe, R.P. Postpartum depression and effects on maternal interaction styles. Oral communication presented to the group of the Project Ipê on May 5 , 2011. 
been developed in England by Cox, Holden and Sagovsky (1987), and validated in Brazil by Santos, Martins and Pasquali (1999). The scale is considered a screening instrument for PPD. Whenever the present study refers to mothers with PPD, it shall be understood mothers with PPD evidence. The instrument is formed by 10 items, graded from zero to three, according to the intensity of the depressive symptom described. The scale total grading ranges from zero to 30, and the interviewees that were considered depressive had a score equal or greater than twelve in the scale. This instrument was applied between the third and fourth postnatal months and reapplied when the baby was eight months old.

\section{Interviews and observations of the dyad at the ages of four, eight and twelve months}

Some interview scripts were designed by the project pediatricians' team and by the first author of this article. The interviews dealt with health and baby development issues and the mother's relationship with the child and the family.

For the building of the assessment tool of the development used in this study, we are partially based on a simplified form of the Denver II test application used for the screening of problems and development (Frankenburg et al., 1990), besides incorporating some more significant requirements of the Gesell and Amatruda (Knobloch \& Passamanick 1990), of clinical Risk Indicators for Child Development (IRDI - sic) (Kupfer et al., 2010), and the M - Chat scale (Robins et al., 2001).

Some items that were considered relevant to the development of babies at the age of four, eight and twelve months have been extracted from these instruments. The included items are shown in Tables 2, 3 and 4. Requirements that could not be observed during the interview were asked to the mother. Trained researchers conducted the interviews/ observations. The adaptation of the instruments had the advantage of being brief, which allowed mothers and babies to be evaluated by other researchers and with other tools in the same visit of the dyads to the research place, in general, far from their own houses.

The indicators were included, for didactic purposes, into four development domains: interactional domain, gross motor domain, adaptive domain and language domain, according, mainly, to the Frankenburg et al. (1990) criteria, except for the domain, which we name interactional, whose meaning was an extension of the personal - social attribute designed by Gesell and used in the Denver II test. Still in the interactional aspect some indicators of development (IRDI, from Kupfer et al., 2010), which correspond to social exchange between the baby and the care taker or other children and adults, were included. The gross motor control refers to postures and global movements; the adaptive motor refers to more specific and fine motor behaviors aimed at objects and daily activities; language is related to nonverbal communication, to verbal communication precursor behaviors and to verbal behaviors themselves.

This study protocol was approved by the Ethics in Research Committee of the University Hospital of the São Paulo University (Universidade de São Paulo), registration n673/06. All participants were informed of the objectives of the project and signed a written informed consent form before being included in the sample.

\section{Results}

\section{Prevalence of postpartum depression}

It has been verified, in the subsamples, that 30.3\% of the mothers showed evidence of PPD when the baby was four months old, 26.4\% when the baby was eight months old, and $25.0 \%$ when the baby was twelve months old. Therefore, there was a slight decrease in the number of mothers with PPD in the interviews and as the child got older.

\section{Neuro-psychomotor development assessment tool}

On most requirements included in the developed instrument to compare the development of both children and mothers with or without PPD, at least 90\% of the children reached the proposed criterion. The following items were the exceptions:

- At the age of four months (Table 2), grabbing the rattle- $77.3 \%$ of the children reached the criterion; asking the mother and pausing to wait for an answer$85.0 \%$ of the children reached the criterion; the mother 
Table 2

Indicators of neuro-psycomotor development of babies of mothers with and without PPD at 4 months of age ( $\mathrm{n}=76 ; 23$ mothers with PPD). São Paulo (SP), 2006-2007

\begin{tabular}{|c|c|c|c|}
\hline \multirow{2}{*}{ Indicators } & \multicolumn{2}{|c|}{$\%$} & \multirow{2}{*}{$p$} \\
\hline & No PPD & With PPD & \\
\hline \multicolumn{4}{|l|}{ Interactional indicators } \\
\hline Mother talks to the child in a style particularly directed at them (baby-talk) & 94.3 & 95.7 & ns \\
\hline When the child cries or screams the mother knows what they want & 92.2 & 86.4 & ns \\
\hline Child reacts to baby-talk & 94.2 & 87.0 & ns \\
\hline Child exchanges looks with the mother & 94.3 & 91.3 & ns \\
\hline Child asks for the mother and waits for response & 84.9 & 78.3 & ns \\
\hline Mother talks to the child using short phrases & 94.3 & 73.9 & $<0.05$ \\
\hline Mother proposes something to the child and waits for their reaction & 86.8 & 87.0 & ns \\
\hline Reacts (smiles, vocalizes) when the mother or another person interacts with them & 98.1 & 91.3 & ns \\
\hline Shows reactions to human voice & 96.2 & 100.0 & ns \\
\hline Child actively searches for the mother's look & 88.7 & 73.9 & $=0.10$ \\
\hline Looks at people & 96.2 & 100.0 & ns \\
\hline Follows people with the look & 92.5 & 95.7 & ns \\
\hline \multicolumn{4}{|l|}{ Language indicators } \\
\hline Laughs & 96.2 & 95.7 & ns \\
\hline Screams & 94.3 & 82.6 & $=0.10$ \\
\hline Growls & 96.2 & 87.0 & ns \\
\hline \multicolumn{4}{|l|}{ Gross motor indicators } \\
\hline Supports the head at $90^{\circ}$ & 100.0 & 95.5 & ns \\
\hline Sits erectly with mother's support & 96.2 & 100.0 & ns \\
\hline Keeps the head still & 100.0 & 100.0 & ns \\
\hline \multicolumn{4}{|l|}{ Adaptive motor indicators } \\
\hline Grabs the rattle & 73.6 & 77.3 & ns \\
\hline Looks at an object & 96.2 & 100.0 & ns \\
\hline Seeks for an objet with the look & 90.6 & 100.0 & ns \\
\hline Follows a moving object $180^{\circ}$ & 84.9 & 91.3 & ns \\
\hline Puts the hands together & 81.1 & 81.8 & ns \\
\hline
\end{tabular}

Note: PPD: Postpartum Depression; ns: non-significant.

proposes something to the child and waits for their reaction - $86.8 \%$ reached the criterion; putting the hands together $-81.8 \%$ reached the criterion (Table 2 ).

- At the age of eight months (Table 3), crying at the presence of strangers $-52.4 \%$ reached the criterion; having favorite objects $-79.7 \%$ reached the criterion; standing, supporting the body while holding to a bar $71.9 \%$ reached the criterion; passing a cube from one hand to the other $-73.8 \%$ reached the criterion; pushing a cube with another $-86.3 \%$ reached the criterion.

- At the age of twelve months (Table 4) bearing with mother's short absences and reacting to long ones 79.3\% reached the criterion; mother asks a child to name what they want $-89.5 \%$ reached the criterion; imitating facial expressions $-89.7 \%$ reached the criterion; starting to walk held by an adult - $86.2 \%$ reached the criterion;

12 drinking from a cup - $86.2 \%$ reached the criterion.

\section{Comparison between children of mothers with or without depression}

The Chi-square tests were applied in order to verify the possible relationships between development milestones of babies, (presence X absence) and indicators of mothers having had or not PPD.

The results obtained in babies' fourth month of life are shown in Table 2. Few statistically significant differences, as well as marginally significant, were found within the following items: the mother talks to a child by saying few sentences $\left(\chi^{2}(1)=6,410 ; p<0.05\right)$, the child actively seeks the mother's gaze; and screams $\left(\chi^{2}(1)=2,640 ; p=0.10\right)$. More non-depressed mothers talked to the babies and more non-depressed mothers' children actively looked for the mother's gaze and expressed themselves through screams. The first two requirements were considered, in 
Table 3

Indicators of neuro-psycomotor development of babies of mothers with and without PPD at 8 months of age (N=88; 23 mothers with PPD). São Paulo (SP), 2006-2007

\begin{tabular}{|c|c|c|c|}
\hline \multirow{2}{*}{ Indicators } & \multicolumn{2}{|c|}{$\%$} & \multirow{2}{*}{$p$} \\
\hline & No PPD & With PPD & \\
\hline \multicolumn{4}{|l|}{ Interactional indicators } \\
\hline Demonstrates likes and dislikes & 96.9 & 100.0 & ns \\
\hline Rejects unknown people & 52.4 & 45.5 & ns \\
\hline Has favorite objects & 079.7 & 77.3 & ns \\
\hline Plays & 95.4 & 100.0 & ns \\
\hline Seeks for a look of approval from an adult & 86.2 & 81.8 & ns \\
\hline Resists the withdrawal of toys & 073.4 & 81.8 & ns \\
\hline Plays hide & 83.1 & 81.8 & ns \\
\hline Follows people with the look & 96.9 & 100.0 & ns \\
\hline Keeps face-to-face periods & 100.0 & 100.0 & ns \\
\hline Reacts to their own name & 92.1 & 100.0 & ns \\
\hline \multicolumn{4}{|l|}{ Language indicators } \\
\hline Vocalizes repeated syllables (papa, mama, dadada) & 84.6 & 90.9 & ns \\
\hline Turns to calling & 95.4 & 100.0 & ns \\
\hline Prsents non-verbal turns, alternance in interaction (protoconversation) & 87.5 & 90.5 & ns \\
\hline \multicolumn{4}{|l|}{ Gross motor indicators } \\
\hline Stands a little on two legs & 85.9 & 90.9 & ns \\
\hline Keeps the head still when pulled to sit & 100.0 & 100.0 & ns \\
\hline Sits without support & 98.5 & 90.9 & $<0.10$ \\
\hline Stands when supported by an adult & 89.2 & 90.9 & ns \\
\hline Supports the body standing when holding on to a bar & 071.4 & 71.9 & ns \\
\hline \multicolumn{4}{|l|}{ Adaptive motor indicators } \\
\hline Holds two cubes at the same time & 88.7 & 90.5 & ns \\
\hline Accepts solid, semi-solid and varied foods & 98.5 & 90.9 & $<0.10$ \\
\hline Eats cookies & 95.4 & 100.0 & ns \\
\hline Looks for toys out of reach & 87.5 & 95.5 & ns \\
\hline Passes a cube from a hand to the other & 073.8 & 57.1 & ns \\
\hline Pushes one cube against another & 68.3 & 57.1 & ns \\
\hline
\end{tabular}

Note: PPD: Postpartum Depression; ns: non-significant.

this study, indicators of development in the interactional field, and the third, in the language field. The three items are related to communication between mother and baby, and it can be considered, in this sample, that at the age of four months and right after the screening tool for PPD was used, children of depressed mothers had more negative indicators in the communicative aspect.

At the age of eight months, few differences were found between children of mothers with or without PPD (Table 3). Only some marginally significant differences were found between the two groups regarding the behaviors: sitting without support, $\left(\chi^{2}(1)=2,816 ; p<0.10\right)$, and accepting solid, semi-solid and varied foods, $\left(\chi^{2}(1)=2,816 ; p<0.10\right)$. In both indicators, children of mothers with PPD had a worse performance.
The findings related to the observed children at twelfth month of life were different from the expected (Table 4): children of mothers with PPD had a better performance than that of children of non-depressed mothers in three aspects. Statistically significant differences were found regarding the items: putting syllables together $\left(\chi^{2}(1)=3,800 ; p=0.05\right)$, holding cubes with their hands and bumping them at each other $\left(\chi^{2}(1)=5,336\right.$; $p<0.05)$, besides marginally significant differences at imitating vocal sounds $\left(\chi^{2}(1)=2,980 ; p<0.10\right)$, and starting to walk held by an adult $\left(\chi^{2}(1)=2,919 ; p<0.05\right)$. Regarding the first three requirements, children whose mothers had PPD performed better than those whose mothers did not have PPD. Only at walking supported by an adult, did the children of non-depressed mothers tend to do better. 
Table 4

Indicators of neuro-psycomotor development of babies of mothers with and without PPD at 12 months of age ( $N=78,19$ mothers with PPD). São Paulo (SP), 2006-2007

\begin{tabular}{|c|c|c|c|}
\hline \multirow{2}{*}{ Indicators } & \multicolumn{2}{|c|}{$\%$} & \multirow{2}{*}{$p$} \\
\hline & No PPD & With PPD & \\
\hline \multicolumn{4}{|l|}{ Interactional indicators } \\
\hline Tolerates mother's absence for short periods and reacts to long periods & 79.3 & 63.2 & ns \\
\hline Mothers starts setting limits & 89.7 & 94.7 & ns \\
\hline Looks with curiosity at what interests the mother & 91.1 & 89.5 & ns \\
\hline Mother asks the child to say what they want & 77.6 & 89.5 & ns \\
\hline Looks at what is pointed by someone else & 94.8 & 100.0 & ns \\
\hline Points & 93.1 & 89.5 & ns \\
\hline Answers by the name & 98.3 & 94.7 & ns \\
\hline Waves (good-bye gesture) & 93.1 & 94.7 & ns \\
\hline Shows alternance of evident shifts & 91.2 & 94.7 & ns \\
\hline Imitates facial expressions & 89.7 & 89.5 & ns \\
\hline Monitors with the look the disposition of an adult & 91.1 & 94.4 & ns \\
\hline Plays, dances or sings & 93.1 & 100.0 & ns \\
\hline \multicolumn{4}{|l|}{ Language indicators } \\
\hline Indicates wishes & 93.1 & 100.0 & ns \\
\hline Makes communicative gestures & 96.6 & 89.5 & ns \\
\hline Imitates vocal sounds & 86.2 & 100.0 & $<0.10$ \\
\hline Joins syllables & 74.1 & 94.7 & $=0.05$ \\
\hline \multicolumn{4}{|l|}{ Gross motor indicators } \\
\hline Stands up & 96.5 & 94.7 & ns \\
\hline Starts walking supported by an adult & 86.2 & 68.4 & $<0.10$ \\
\hline Climbs steps crawling & 81.0 & 83.3 & ns \\
\hline \multicolumn{4}{|l|}{ Adaptive motor indicators } \\
\hline Plays ball with researcher & 83.9 & 78.9 & ns \\
\hline Hits two cubes held in their hands & 77.2 & 100.0 & $<0.05$ \\
\hline Grabs using thumb & 93.1 & 100.0 & ns \\
\hline Drinks from a cup & 86.2 & 84.2 & ns \\
\hline
\end{tabular}

Note: PPD: Postpartum Depression; ns: non-significant.

\section{Discussion}

\section{Postpartum depression prevalence}

A prevalence of $30.0 \%$ of mothers with puerperal symptoms when the baby was 4 months old, $26.4 \%$ at the age of 8 months and $25.0 \%$ at the age of 12 months was observed in this study sample. According to Silva (2008), Brazilian studies pointed out PPD prevalence between $13.4 \%$ and $37.1 \%$. The variation found may be due to both the use of different sorting tools and diagnosis, and to risk factors and protection involving the mother-baby dyad. The prevalence of puerperal depression within the present study is compatible to that of populations subject to risk factors found within

14 many studies: low social economic level and schooling, being single or separated (Beck 1998; Silva \& Botti, 2006). Having Silva (2008), studied the same cohort, she pointed out the following risk factors associated to PPD: poor education, high number of children, previous depression history; complications during pregnancy; high level of pregnancy rejection; low social support level; baby's father unemployment; the mother having been punished or rejected by her parents in her childhood.

The focused subsamples in this study showed that the slight decline in the frequency of mothers with PPD as the baby grows older might have been random or it might mean that those mothers were not willing to participate in this study any longer. Still, the PPD levels observed are higher than those verified in less vulnerable groups of women with a higher socioeconomic status, both in Brazil and in other countries. 


\section{Neuro-pshychomotor development assessment tool}

Although there have not been done any statistical tests that could ascertain the sensitivity of the tool used in this work for assessing development, the chosen items seem to have been appropriated to the objective: comparing two groups of babies of the same cohort, regarding maternal depression, because in most items, $90 \%$ of the children reached the pre-established criteria expected for their age.

Supposing the items in which $75 \%$ of the children reached the criterion are acceptable, two requirements would be eliminated from the instrument: at the age of leight months, coping well with short absences of the mother, and reacting to long absences, besides standing with support of a bar.

Evidently it is interesting that future studies, with a higher number of participants, be conducted for the determination of the sensibility, validation and precision of the used tool. It should be noted, however, that besides the possibility of being used as a comparison factor between the two studied groups, an advantage of this tool was its simple and fast application.

\section{Effects of postpartum depression on development}

The obtained results in the present work highlight that PPD effects are not clear regarding babies development. The Psychosocial Pediatrics Committee states that"the associations among maternal depression, maternal behavior and the manifestations in children are complex and not all studies find a relationship between maternal depression and indicators of deficient maternal care" (Canadian Paediatrics Society, 2004, p.2).

Variables that can influence depressed mothers' children's behavior are the kind, the seriousness, the chronicity and the duration of the depression, the sample heterogeneity and potentiated risk factors like family adversity, low social support and financial stress. Besides, stressful factors can contribute to the appearance or worsening of problems in children, even though there is lack of maternal depression (Canadian Paediatrics Society, 2004).

The slight difference found between the level of development of children of mothers with or without PPD is compatible to the results of some studies. We mentioned, in the introduction, the findings of Fonseca et al. (2010) and of Grote et al. (2010), who did not state, respectively, effects of PPD on the mother - baby interaction and on children's growth. Other mentioned studies also stated the non-influence of maternal depression over some babies' behavioral characteristics (Boyd et al., 2006; Hartley et al., 2010).

The results of the present work illustrate the complexity of the relationship between maternal depression and babies' development, because, in this relationship, internal factors and aspects of the mother, the baby, the mother-baby interaction, as well as the diversity of environmental characteristics that surround them are involved.

Considering that development is a product of the interaction of biological characteristics of the child and those of the environment that, surrounds them, one must take into consideration that among internal factors that protect them or make them vulnerable, are their temperament and their resilience to stressful factors Klein and Linhares (2007) describe how different temperaments react to stressful events. The authors say: "different children may respond to the same social investments of development promotion in different ways, with their individual characteristics influencing successful and maladjusted paths ...among these personal relevant traits, temperament stands out" (Klein \& Linhares, 2007, p.35). H. Papousek and M. Papousek (1997) pointed out the evidences that babies' difficult temperament could lead to PPD in their mothers. Avissi and Hubin-Gayte (2006) state, in the same sense, that babies' irritability is one of the factors that lead to maternal depression.

Another concept that contributes to the explanation of the few differences found between the two groups of children that were studied, (children of mothers with or without PPD) is resilience. Resilience is a concept, under the psychological point of view, that can be understood as the ability people have to face and overcome adversities, without causing major psychological damage (Silveira \& Mahfoud, 2008). Other authors such as Beck (1998) and Frizzo and Piccinini (2007), consider that resilience factors could have compensatory effects of a raising depressive environment. Cummings and Davies (1994) point out that even in families in which mothers or fathers are depressed, there might be a healthy enough functioning 
that provides children with care and affection. They also support that the family history of children that live under these conditions may bring positive consequences, which favor the development of sensibility for feelings and needs of other people, a very important adaptive factor in different contexts.

On the maternal side, in turn, factors of protection in the relationship with the baby, besides environmental characteristics, are considered: the adaptability, the sensitivity, the mother's ability to cope with stressful facts and to buffer the depression effects on the relationship with the baby (Fonseca et al., 2010).

Although minor differences have been found between children of mothers with or without PPD, some differences deserve to be mentioned. The differences found in the babies' fourth month of life refer to interactional and communicative aspects: a smaller number of depressed mothers talked to their babies, probably because of their own depressive moods. Albeit marginally significant, children of mothers without DPP were more active in presenting communication signals, such as shouting and looking for the mother's look. Such data, though small in number, are in accordance with the findings in literature that indicate that fewer face to face exchanges happen between depressed mothers and their babies dyads (Beck, 1998; Frizzo \& Picinini, 2007; Motta et al., 2005; Scwengber \& Picinini, 2003), and suggest that some harm, regarding the interactionalcommunicative aspect, was done, in some mother-baby dyads in the fourth month of life, because of maternal depression.

Only two marginally significant differences favoring children of non-depressed mothers were found in babies at the age of eight months of life: sitting without support and accepting varied kinds of food. This finding could be explained by the fact that the maternal depression may occasion less sensor-motor stimulation in babies.

While the data obtained at the end of the first year of life show a tendency toward superiority in gross motor skills of children of mothers without depression (they start walking supported by an adult), there are signs of better language performance and adaptive motor behavior on the part of children of mothers who had postpartum depression. Indeed, there is some evidence that there may be a negative relationship between maternal directivity and certain measures of child language development (Tomasello \& Farrar 1986). That is, it is possible to assume that depressed mothers were less directive in relation to their children, thus providing a faster advancement of oral language. In other words, accepting the hypothesis that depressed mothers gave less direct attention to their children, some compensatory effect may have occurred and enabled those children to develop oral language more quickly, facilitating their communication with the mother and other adults, so that they could express their desires, feelings and intentions more clearly.

Such statements are only hypothetical. What seems undeniable is that the relationship between postpartum depressions and child development is far from simple or linear. It is rather mediated by a number of factors identified in several cited studies, and influenced by other marked aspects which need further clarification and confirmation. Large random samples are necessary to control the variables whose influence has been evidenced in the literature, and more refined statistical models need to be applied to determine the relative influence of all of them. External risk factors have been more widely observed; however, there is need to invest in research to investigate mother and child internal states, including thoroughly organic aspects, as the case of hormonal changes, and those that concern the severity and duration of the depressive mother's mood, the resilience both of mother and baby and its relationship with postpartum depression.

\section{References}

Associação Brasileira de Empresas de Pesquisa. (2009). Critérios para classificação econômica da ABEP. Recuperado em maio 2, 2011, disponível em <http://www.abep. org/novo/Content.aspx?ContentID=302>.

Ayissi, L., \& Hubin-Gayte, M. (2006). Irritabilité du nouveau-né et dépression maternelle du post-partum. Neuropsychiatrie de l'enfance et de l'adolescence, 54(2), 125-132.

Beck, C. T. (1998). The effects of postpartum depression on child development: A meta-analysis. Archives of Psychiatric Nursing, 12(1), 12-20.

Boyd, R. C., Zayas, L. H., \& McKee, M. D. (2006). Mother-infant interaction, life events and prenatal and postpartum depressive symptoms among urban minority women in primary care. Maternal and Child Health Journal, 10(2), 139-148.

Canadian Paediatric Society. (2004). Maternal depression and child development. Paediatric Child Health, 9(8), 
575-583. Recuperado em fevereiro 14, 2010, disponível em <http://www.cps.ca/english/statements/pp/pp 04-03.htm>.

Cox, J. L., Holden, J. M., \& Sagovsky, R. (1987). Detection of postnatal depression: Development of the 10-item Edinburgh Postnatal Depression Scale. British Journal of Psychiatry, 150, 782-786.

Cummings, E. M., \& Davies, P. T. (1994). Maternal depression and child development. The Journal of Child Psychology and Psychiatry, 9(8), 575-583.

Fonseca, V. R. J. R. M., Silva, G. A., \& Otta, E. (2010). Relação entre depressão pós-parto e disponibilidade emocional materna. Caderno de Saúde Pública, 26(4), 738-746.

Frankenburg, W. K., Dodds, J., Archer, P., Shapiro, H., \& Bresnick, B. (1990). Denver II screening manual. Denver: Denver Development Materials Incorp.

Frizzo, G. B., \& Piccinini, C. A. (2005). Interação mãe-bebê em contexto de depressão materna: aspectos teóricos e empíricos. Psicologia em Estudo, 10(1), 47-55.

Frizzo, G. B., \& Piccinini, C. A. (2007). Depressão materna e interação triádica pai-mãe-bebê. Psicologia: Reflexão e Crítica, 20(3), 351-360.

Grote, V., Vik, T., Von Kries, R., Luque, V., Socha, J., \& Verduci, E., et al. (2010). Maternal postnatal depression and child growth: A European cohort study. Bio Med Central Pediatrics, 10(1), 14-21.

Haggerty, R. J., Sherrod, L. R., Gamezy, N., \& Rutter, M. (2000). Stress, risk and resilience in children and adolescents: Process, mechanisms and interventions. New York: Cambridge University Press.

Hartley, C., Pretorius, K., Mohamed, A., Laughton, B., Madhi, S., \& Cotton, M. F., et al. (2010). Maternal postpartum depression and infant social withdrawal among human immunodeficiency virus (HIV) positive mother-infant dyads. Psychology Health \& Medicine, 15(3), 278-287.

Klein, V. C., \& Linhares, B. C. (2007). Temperamento, comportamento e experiência dolorosa na trajetória de desenvolvimento da criança. Paidéia, 17(36), 33-44.

Knobloch, H., \& Passamanick, B. (1990). Gesell e Amatruda diagnóstico do desenvolvimento. Rio de Janeiro: Atheneu.

Kupfer, M. C. M., Jerusalinsky, A. N., Bernardino, L. M. F., Wanderley, D., Rocha, P. S. B., \& Molina, S. E., et al. (2010). Valor preditivo de indicadores clínicos de risco para o desenvolvimento infantil: um estudo a partir da teoria psicanalítica. Revista Latinoamericana de Psicopatologia Fundamental, 13(1), 31-52.

Motta, M. G., Lucion, A. B., \& Manfro, G. G. (2005). Efeitos da depressão materna no desenvolvimento neurobiológico e psicológico da criança. Revista de Psiquiatria do Rio Grande do Sul, 27(2), 165-176.

Papousek, H., \& Papousek, M. (1997). Fragile aspects of early social integration. In L. Murray \& P. J. Cooper (Eds.),
Postpartum depression and child development (pp.35-53). New York: The Guilford Press.

Ribeiro, C.S. (2002). Depressão pós-parto e relação mãe-filho. Psiqweb. Recuperado em dezembro 8, 2005, disponível em <http://gballone.sites.uol.com.br/colab/carmen. html>.

Robins, D. L. (2008). Screening for autism spectrum disorders in primary care settings. Autism, 12(5), 537-556. Retrieved March 26, 2011, from <http://aut.sagepub.com/cgi/ content/abstract/12/5/537>. doi: 10.1177/13623613080 94502.

Robins, D., Fein, D., Barton, M. L., \& Green, J. A. (2001). The modified checklist for autism in toddlers: An initial study investigating the early detection of autism and pervasive developmental disorders. Journal of Autism and Developmental Disorders, 31(2), 131-144.

Santos, M. F. S., Martins, F. C., \& Pasquali, L. (1999). Escalas de auto-avaliação de depressão pós-parto: estudo no Brasil. Revista de Psiquiatria Clínica, 26(2), 32-40.

Sapienza, G., \& Pedromônico, M. R. M. (2005). Risco, proteção e resiliência no desenvolvimento da criança e do adolescente. Psicologia em Estudo, 10(2), 209-216.

Schwengber, D. D. S., \& Piccinini, C. A. (2003). O impacto da depressão pós-parto para a interação mãe-bebê. Estudos de Psicologia (Natal), 8(3), 403-411.

Silva, E. T., \& Botti, N. C. L. (2006). Depressão puerperal: uma revisão de literatura. Revista Eletrônica de Enfermagem, 7 (2), 231-236. Recuperado em dezembro 12, 2008, disponível em <http://www.fen.ufg.br/>.

Silva, G. A. (2008). Estudo longitudinal sobre prevalência e fatores de risco para depressão pós-parto em mães de baixa renda (Dissertação de mestrado não-publicada). Programa de Pós-Graduação em Psicologia, Universidade de São Paulo). Recuperada em maio 14, 2011, disponível em <http://www.teses.usp.br/teses/disponiveis/47/ 47132/tde-29072009-162342/pt-br.php>.

Silveira, D. R., \& Mahfoud, M. (2008). Contribuições de Viktor Emil Frankl ao conceito de resiliência. Estudos de Psicologia (Campinas), 25(4), 567-576. doi: 10.1590/S0103-166X20 08000400011.

Tomasello, M., \& Farrar, M. J. (1986). Joint attention and early language. Child Development, 57(6), 1454-1463.

Tronick, E., \& Weinberg, M. K. (1997). Depressed mothers and infants: The failure to form dyadic states of consciousness. In L. Murray \& P. J. Cooper (Eds.), Postpartum depression and child development (pp.54-81). New York: Guilford Press.

Wallon, H. (1995). A evolução psicológica da criança. Lisboa: Edições 70. (Originalmente publicado em 1941).

Received on: 26/7/2011

Final version on: 27/2/2012

Approved on: 16/4/2012 
